\title{
Shear buckling behavior of a plate composite girder using concrete-filled steel tube structures
}

\author{
Jun-Gi $\operatorname{Sim}^{1}[$ \\ Received: 6 September 2018 / Accepted: 13 August 2019 / Published online: 26 August 2019 \\ (c) The Author(s) 2019
}

\begin{abstract}
In this study, the shear buckling behavior of plate girders using concrete-filled steel tube structure was verified by nonlinear finite element analysis using CEB-FIP 1990 code. In addition, shear buckling tests were carried out on the model specimens and compared with the analysis. As a result, it was confirmed that the proposed plate girder improved the shear buckling resistance compared to the general plate girder. Also, by comparing the test results with the analysis, we propose that the proposed CEP-FIP code is a reasonable analysis. Particularly, as a result of comparing the maximum deflection displacement of the plate girder, it was found that the proposed girder improved the shear buckling resistance performance due to the confinement effect of the concrete-filled steel tube structure than general plate girder.
\end{abstract}

Keywords Shear buckling $\cdot$ Plate composite girder $\cdot$ Concrete-filled steel tube $\cdot$ Mock-up test $\cdot$ Finite element analysis

\section{Introduction}

The I-shaped plate girder is widely used as a flexural member, because its section rigidity is efficient. However, in the case of such a general plate girder, there is a problem of shear buckling, and therefore research has been carried out to overcome this problem.

Lee et al. (1996) studied the shear buckling of plate girders by boundary condition by finite element modeling to confirm the shear buckling behavior of plate girders. Höglund (1997) studied the shear buckling resistance of plate girders using steel and aluminum materials. Lee and Yoo (1998) performed a finite element nonlinear analysis of the shear buckling strength of plate girders for pure shear force. Baskar et al. (2002) performed a finite element nonlinear analysis on the moment and shear loads of steel-concrete composite plate girder. At this time, in Japan, Nakamura et al. (2002) studied a girder utilizing a concrete-filled steel tube structure. Wu et al. (2006) studied the application of concrete-filled steel tube structures to the ribs of arch bridges for earthquakes. Bambach et al. (2008) conducted

Jun-Gi Sim

sjk0605@korea.ac.kr

1 Structural Engineering Research Division, Korea Bridge Institute Co., Ltd, Bucheon-Si, Gyeonggi-do 14548, Republic of Korea a comparative study of the lateral load impacts of sections using concrete-filled steel tube structures and general hollow sections. Okamoto et al. (2012) studied girder-type girders reinforced with arch ribs of concrete-filled steel tube structures. Sim (2017) has been working on reinforcing the upper and lower flanges with a concrete-filled steel tube structure on the plate girder. Chen et al. (2018) studied shear buckling behavior for stainless steel plate girders. At this time, studies were performed on improving the shear buckling resistance of the plate girders using corrugated steel sheets (Darmawan et al. 2018). To improve the shear buckling resistance of the plate girder up to now, a method of controlling the compression flange thickness by studying the shear buckling behavior of each material boundary condition was used. In addition, a method of improving shear buckling resistance using a corrugated steel sheet was utilized. However, in the case of conventional plate girders, research to improve the shear buckling resistance by the thickness of the compression flange is dominant. In addition, no studies have been conducted to improve the shear buckling resistance of plate girders using concrete-filled steel tube structures as a new method. Therefore, in this study, I propose the utilization of the concrete-filled steel tube structure which is widely used now as a new method other than the existing method of adjusting the compression flange thickness to improve the shear buckling resistance of the plate girder. 


\section{Shear buckling test of the proposed girder}

\section{Basic concept of shear buckling test body}

For general plate girders, it is recommended that the compression flange thickness should be at least 1.1 times the thickness of the web plate in accordance with the equation (6.10.2.2-3) in 6.10.2.2-Flange proportions of the AASHTO LRFD bridge design specifications (Specifications 2012). As shown in Fig. 1, specimens of the concrete-filled steel tube structure and a cross-section of the normal plate were manufactured with the same stiffness of the compression flange portion.

In the plate girder using concrete-filled steel tube structure, $b_{\mathrm{fc}}^{\prime}$ is the width of the upper flange, $t_{\mathrm{fc}}^{\prime}$ is the thickness of the upper flange, and $h$ is the height of the filled concrete. $b$ is the width of the filled concrete, and $t_{\mathrm{w}}^{\prime}$ is the thickness of the web plate abutting the upper flange. In a typical plate girder, $t_{\mathrm{fc}}$ is the thickness of the upper flange abutting the web plate, $D$ is the abutting height of the lower flange, $t_{\mathrm{w}}$ is the thickness of the web plate, $b_{\mathrm{ft}}$ is the width of the lower flange, $t_{\mathrm{ft}}$ is the thickness of the lower flange, $D^{\prime}$ is the distance from the neutral axis to the center of the upper flange of the concrete-filled steel tube, and $b_{\mathrm{fc}}$ is the upper flange width.

\section{Shear buckling test specification and test method}

Detailed specifications of the shear buckling specimen are shown in Table 1. Based on the basic concept of cross-section, it was constructed so that the compressive portion of the concrete-filled steel tube structure from the center of the entire cross-section and the center of the compression flange of the general plate coincide with each other. The concrete used was C40 with a compressive strength of $40 \mathrm{MPa}$, and the steel was HSB500 with an allowable stress of $230 \mathrm{MPa}$. The shear buckling test is shown in Figs. 2 and 3, the total span length $L$ was $3.3 \mathrm{~m}$ and the span was $3.0 \mathrm{~m}$. The boundary condition was a roller hinge and was carried out at three points until shear buckling occurred at the mid-point of the specimen with a maximum capacity of $5000 \mathrm{kN}$.

Figure 4 shows the three-point load test for each specimen, and each specimen was positioned at a distance of $1.5 \mathrm{~m}$ from the specimen.

To find the maximum vertical displacement, the displacement meter was installed with a vertical direction displacement meter at $2 / 4 \mathrm{~L}$ of the lower flange and the displacement was measured. Also, strain rate was measured at $2 / 4 \mathrm{~L}$ of lower flange bottom and 1/4L of lower flange bottom to determine shear buckling point.

\section{Theoretical background for finite element analysis}

Since the concrete-filled steel tube structure is applied to improve the shear buckling resistance of the plate girder, the structural behavior of the proposed plate girder should be tested for the ultimate load where buckling occurs. For this purpose, we propose structural analysis considering material nonlinear analysis using CEB-FIP 1990 material model (CEB 1993).

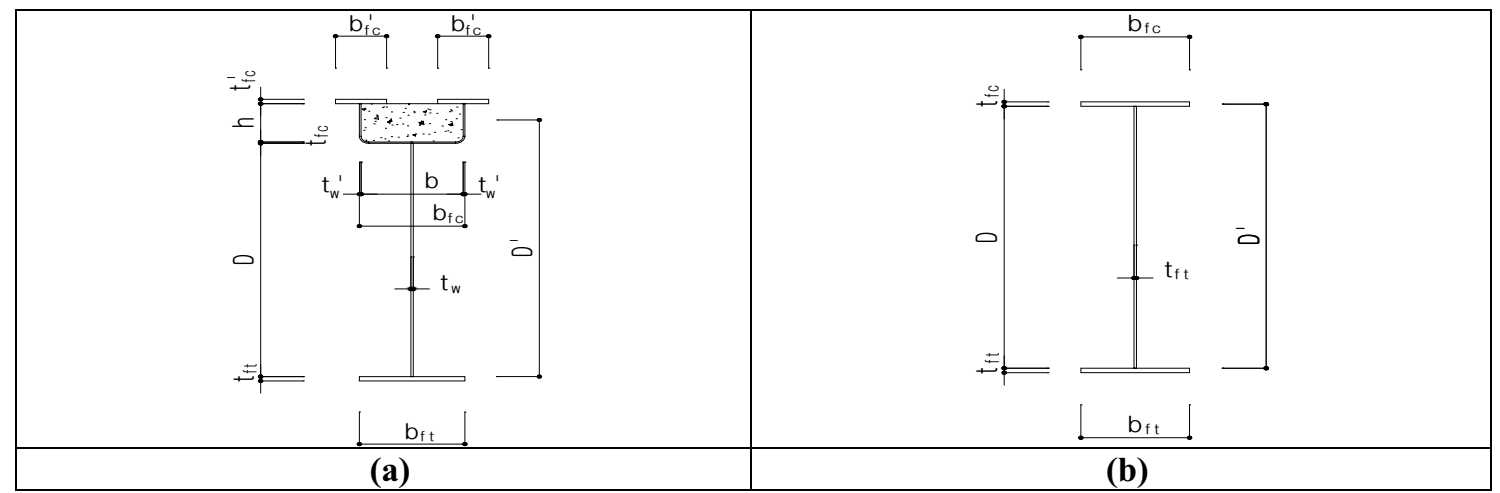

Fig. 1 Definitions of $\mathbf{a}$ proposed plate girder and $\mathbf{b}$ ordinary plate girder

Table 1 Pure steel sections of proposed plate girder and ordinary plate girder (unit: $\mathrm{mm}$ )

\begin{tabular}{lllllllllllll}
\hline Types & $b_{\mathrm{fc}}^{\prime}$ & $t_{\mathrm{fc}}^{\prime}$ & $h$ & $t_{\mathrm{w}}^{\prime}$ & $b_{\mathrm{fc}}$ & $t_{\mathrm{fc}}$ & $D$ & $t_{\mathrm{w}}$ & $b_{\mathrm{ft}}$ & $t_{\mathrm{ft}}$ & $D^{\prime}$ & $L$ \\
\hline Proposed plate girder & 150 & 10 & 150 & 8 & 316 & 8 & 1342 & 8 & 316 & 12 & 1427 & 3300 \\
Ordinary plate girder & - & - & - & - & 316 & 45 & 1405 & 8 & 316 & 12 & 1427 & 3300 \\
\hline
\end{tabular}



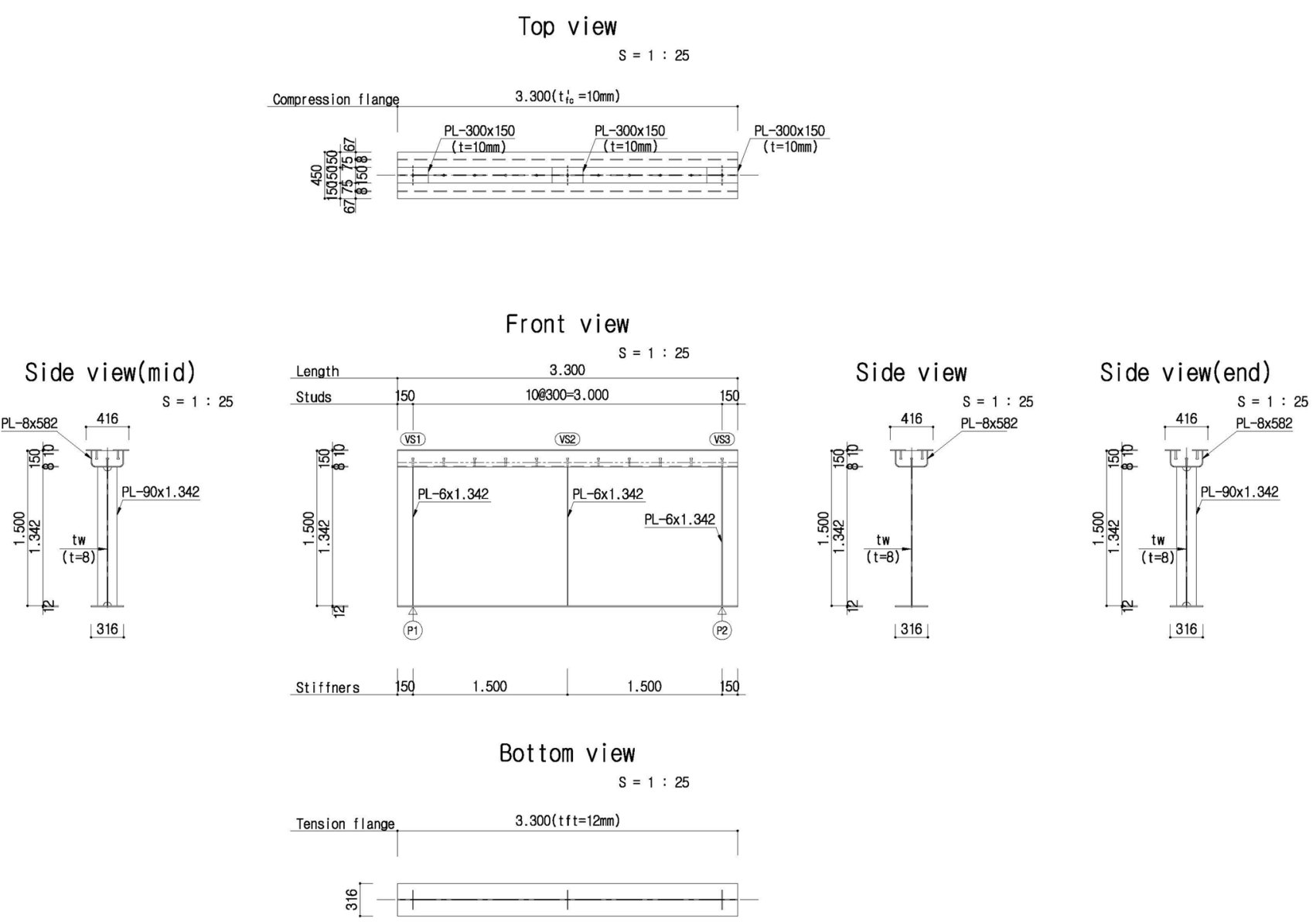

Fig. 2 A specimen of proposed plate girder

Therefore, the stress-strain curve of the concrete is applied according to the CEB-FIP 1990 material model. The elastic modulus of ordinary concrete is calculated using Eq. (1).

$E_{\mathrm{ci}}=E_{\mathrm{co}}\left[\frac{f_{\mathrm{ck}}+\Delta f}{f_{\mathrm{cmo}}}\right]^{1 / 3}$,

where $E_{\mathrm{ci}}$ is the elastic modulus of concrete at 28 days; $f_{\mathrm{ck}}$ is the compressive strength of concrete; $\Delta f=8 \mathrm{MPa}$; $f_{\mathrm{cmo}}=10 \mathrm{MPa}$; and, $E_{\mathrm{co}}=2.15 \times 10^{4} \mathrm{MPa}$.

The stress-strain curve appears generally in the shape plotted in Fig. 5.

The stress-strain relation of concrete complies with Eq. (2):

$\sigma_{\mathrm{c}}=-\frac{\frac{E_{\mathrm{ci}}}{E_{\mathrm{c} 1}} \frac{\varepsilon_{\mathrm{c}}}{\varepsilon_{\mathrm{cl}}}-\left(\frac{\varepsilon_{\mathrm{c}}}{\varepsilon_{\mathrm{cl}}}\right)^{2}}{1+\left(\frac{E_{\mathrm{ci}}}{E_{\mathrm{c} 1}}-2\right) \frac{\varepsilon_{\mathrm{c}}}{\varepsilon_{\mathrm{c} 1}}} f_{\mathrm{cm}}$ for $\left|\varepsilon_{\mathrm{c}}\right|<\left|\varepsilon_{\mathrm{c}, \text { lim }}\right|$,

where $E_{\mathrm{ci}}$ is the tangent elastic modulus; $\sigma_{\mathrm{c}}$ is the compressive stress $(\mathrm{MPa}) ; \varepsilon_{\mathrm{c}}$ is the compressive strain; $\varepsilon_{\mathrm{c} 1}=-0.0022 ; f_{\mathrm{cm}}=f_{\mathrm{ck}}+\Delta f$ (maximum compressive stress); and, $E_{\mathrm{c} 1}=f_{\mathrm{cm}} / 0.0022$ (secant elastic modulus at $\left.f_{\mathrm{cm}}\right)$.

The maximum stresses and strains of the compressive part to exert the confinement effect of the concrete-filled steel tube are shown in Eq. (3), which is the equation proposed by Hu et al. (2003):

$f_{\mathrm{cc}}=f_{\mathrm{c}}+k_{1} f_{1}$

$\varepsilon_{\mathrm{cc}}=\varepsilon_{\mathrm{c}}\left(1+k_{2} \frac{f_{1}}{f_{\mathrm{c}}}\right)$,

where $f_{\mathrm{cc}}$ is the maximum compressive stress of concrete reflecting the confinement effect (MPa); $\varepsilon_{\mathrm{cc}}$ is the maximum compressive strain of concrete reflecting the confinement effect; $k_{1}=4.1$ (obtained experimentally); $k_{2}=20.5$ (obtained experimentally); and, $f_{1}=0.3$ (obtained experimentally).

Figure 6 is the stress-strain curve of the concrete reflecting the confinement effect on compressive strength. The maximum compressive stress $f_{\text {cc }}$ of the filled concrete was $41.23 \mathrm{MPa}$ and the maximum compressive strain $\varepsilon_{\mathrm{cc}}$ was $2538.25 \mu \varepsilon$. However, even at the maximum load of $2750 \mathrm{kN}$ 
Top view

$$
S=1: 25
$$

Compression flange $3.300\left(t_{\mathrm{fc}}=45 \mathrm{~mm}\right)$

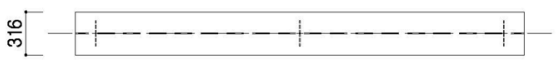
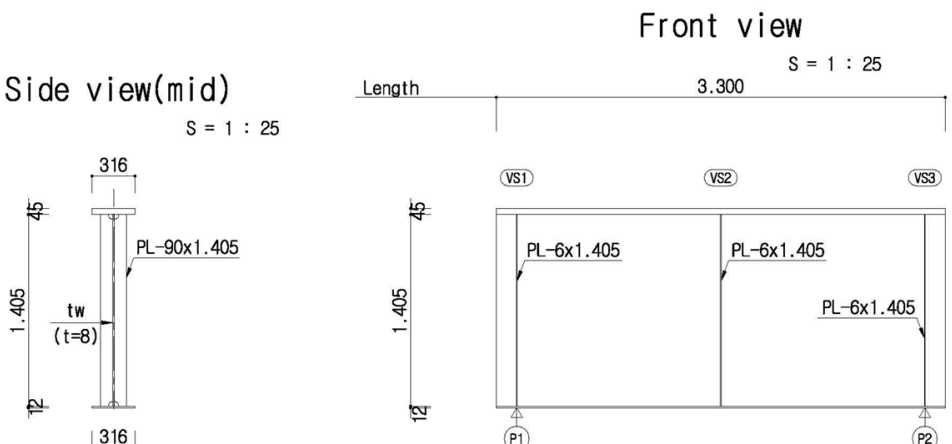

Side view

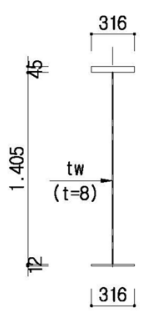

Side view(end) $S=1: 25$

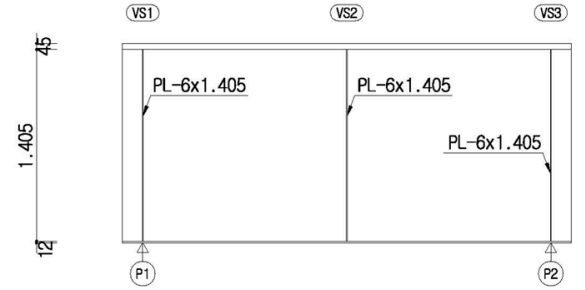

Stiffners $\quad 150 \quad 1.500 \quad 1.500 \quad 150$ Bot tom view $S=1: 25$

Tension flange. $3.300(\mathrm{tft}=12 \mathrm{~mm})$

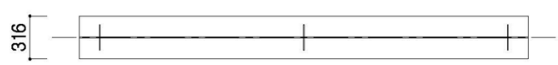

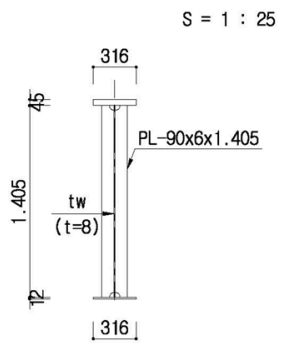

Fig. 3 A specimen of ordinary plate girder

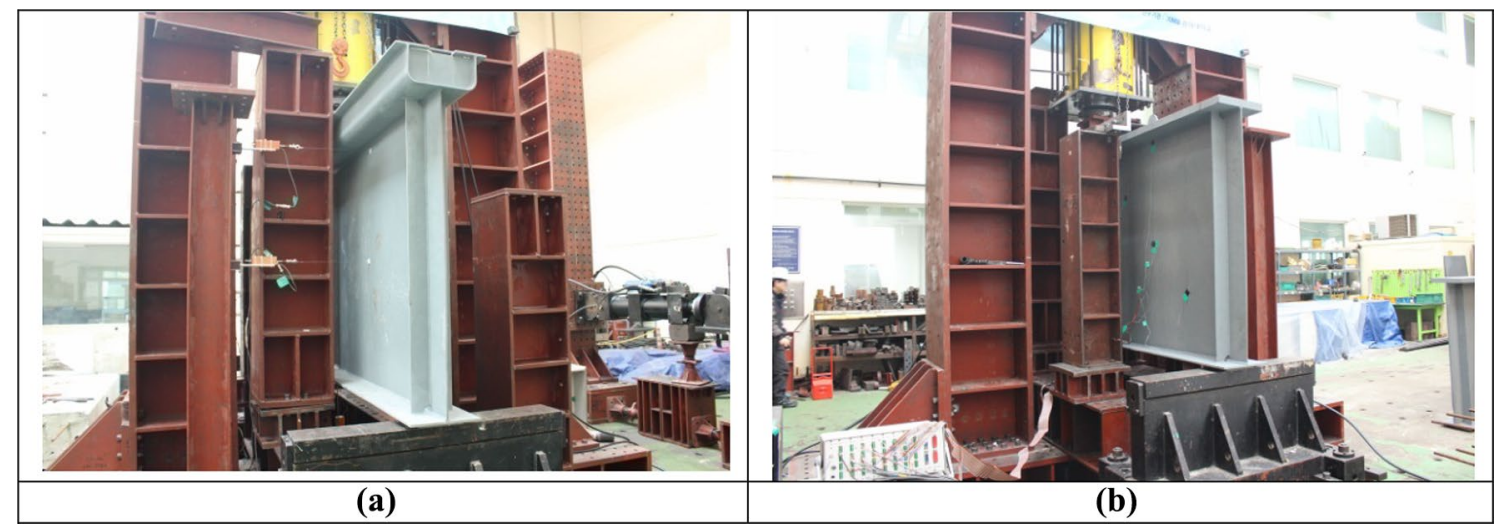

Fig. 4 Shear buckling tests of $\mathbf{a}$ proposed plate girder and $\mathbf{b}$ ordinary plate girder 


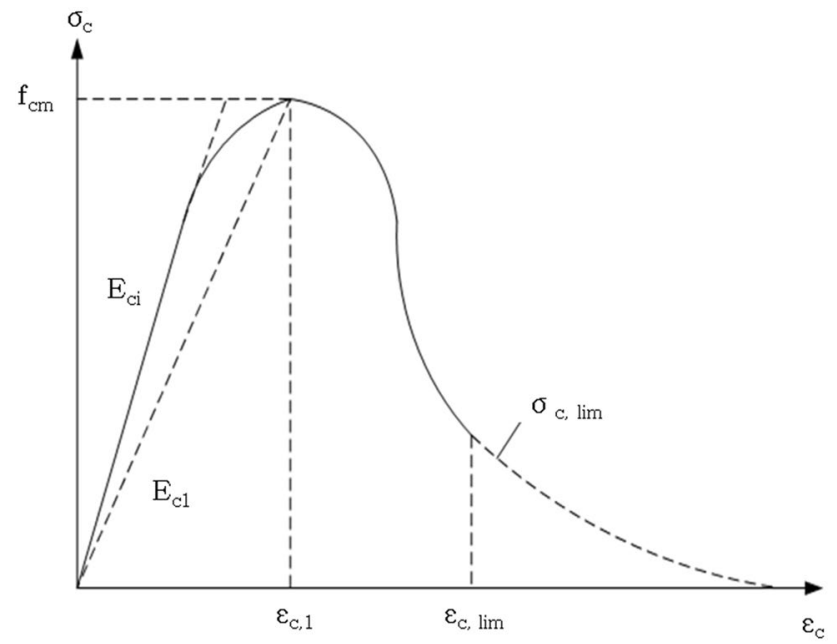

Fig. 5 Uniaxial compression stress-strain curve using CEP-FIP 1990

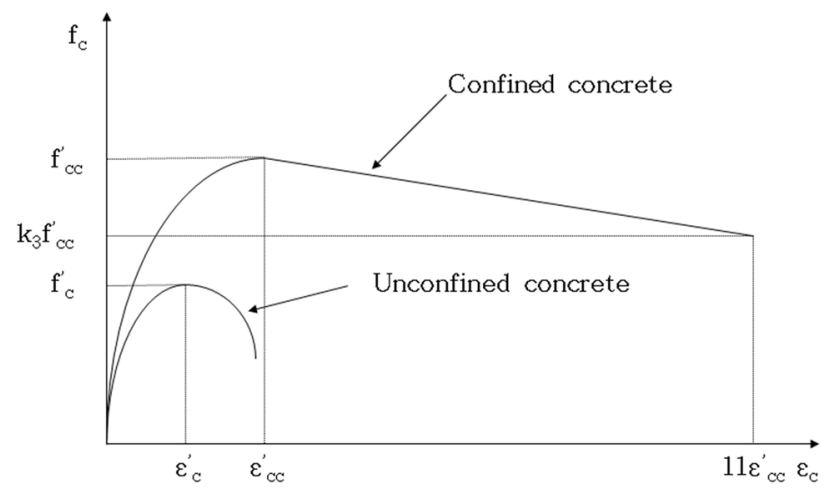

Fig. 6 Confinement effect of the confined concrete

of shear buckling test, a strain of $1200 \mu \varepsilon$ was generated and the strain to reflect the constraining effect could not be reached.

In other words, because the compressive strain did not reach the strain to reflect the confinement effect of the concrete-filled steel tube even at the maximum load, the proposed material model did not reflect the constraining effect.

\section{Finite element model}

The proposed girder consists of outer steel, inner filled concrete and vertical stiffener. The material model was applied with reference to CEB-FIP 1990. The unit weight of concrete was $2100 \mathrm{~kg} / \mathrm{m}^{3}$, elastic modulus was 30,827.5 $\mathrm{MPa}$ and Poisson ratio was 0.16 . The external steel is HSB500 with a unit weight of $7698 \mathrm{~kg} / \mathrm{m}^{3}$, an
Table 2 Designation as results of experiment and FEA

\begin{tabular}{ll}
\hline Designation & Explanation of the designation \\
\hline$D_{\mathrm{vm}}$ & Maximum displacement of the proposed girder at $2 / 4 \mathrm{~L}$ \\
$\varepsilon_{\mathrm{m}}$ & Maximum strain of the proposed girder at $2 / 4 \mathrm{~L}$ \\
$\varepsilon_{\mathrm{q}}$ & Maximum strain of the proposed girder at $1 / 4 \mathrm{~L}$ \\
\hline
\end{tabular}

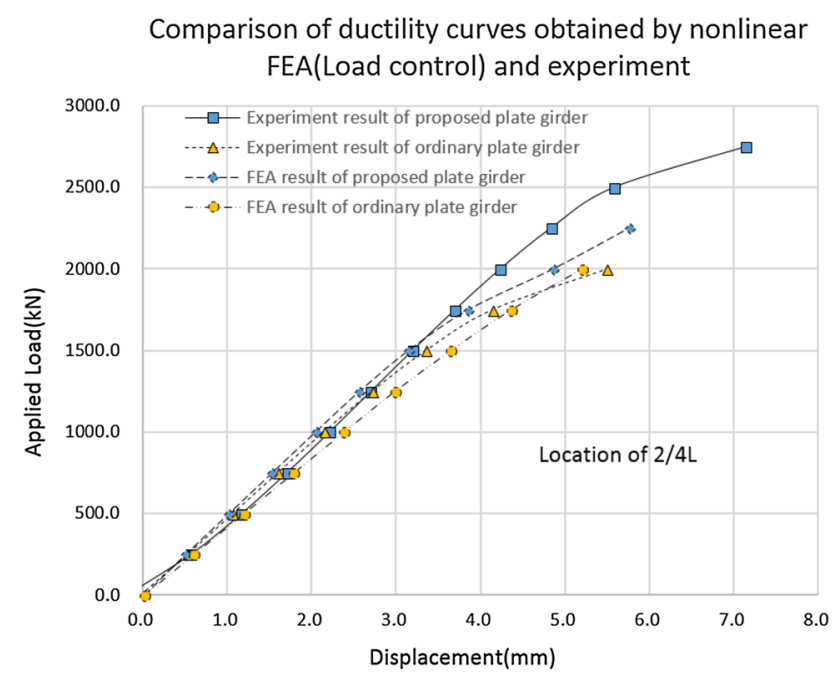

Fig. 7 Comparison of load-displacement curves obtained by experiment and nonlinear FEA (load control) at $2 / 4 \mathrm{~L}$

elastic modulus of $205 \mathrm{GPa}$ and a Poisson ratio of 0.3 . In case of ordinary plate girder, the same material properties as the proposed girder are applied except for concrete. And each girder was modeled using three-dimensional solid element. The analytical method was performed until the material nonlinear modeling converged with the load control and the displacement control.

Table 2 shows the location of the position of the displacement and strain gauges of the plate girder and the general plate girder using the concrete-filled steel tube for the shear buckling test and the finite element model, respectively.

\section{Experimental and finite element analysis results}

The maximum displacement of the plate girder and the general plate girder is shown in Fig. 7, and the strength and ductility of the proposed girders increased from that of ordinary plate girders. In addition, as shown in Table 3, the applied load difference between the proposed girder and the normal plate girder increased to about $1000 \mathrm{kN}$ by about 1.5 times at the maximum deflection of $7 \mathrm{~mm}$. These results are similar 
Table 3 Load-displacement relationship results of experiment and nonlinear FEA (load control) at 2/4L

\begin{tabular}{|c|c|c|c|c|c|c|}
\hline \multirow[t]{2}{*}{$D_{\mathrm{vm}}(\mathrm{mm})$} & \multicolumn{6}{|l|}{ Applied load (kN) } \\
\hline & $\begin{array}{l}\text { Experiment result of } \\
\text { proposed plate girder }\end{array}$ & $\begin{array}{l}\text { Experiment result of } \\
\text { ordinary plate girder }\end{array}$ & $\begin{array}{l}\text { FEA result of pro- } \\
\text { posed plate girder }\end{array}$ & $\begin{array}{l}\text { FEA result of ordi- } \\
\text { nary plate girder }\end{array}$ & $\begin{array}{l}\text { Error of proposed } \\
\text { plate girder }\end{array}$ & $\begin{array}{l}\text { Error of } \\
\text { ordinary plate } \\
\text { girder }\end{array}$ \\
\hline 0.0 & 54.5 & 9.7 & 0.0 & 0.0 & 54.5 & 9.7 \\
\hline 0.5 & 224.6 & 233.9 & 238.4 & 220.4 & $(13.8)$ & 13.5 \\
\hline 1.0 & 425.8 & 466.7 & 476.7 & 440.8 & $(50.9)$ & 25.9 \\
\hline 1.5 & 651.1 & 702.1 & 715.1 & 661.3 & $(64.0)$ & 40.8 \\
\hline 2.0 & 893.5 & 934.1 & 953.5 & 881.7 & $(60.0)$ & 52.4 \\
\hline 2.5 & 1145.9 & 1156.9 & 1112.4 & 1028.6 & 33.5 & 128.3 \\
\hline 3.0 & 1401.2 & 1364.5 & 1271.3 & 1175.6 & 129.9 & 189.0 \\
\hline 3.5 & 1652.6 & 1551.0 & 1509.7 & 1396.0 & 142.9 & 155.1 \\
\hline 4.0 & 1892.8 & 1710.5 & 1748.0 & 1616.4 & 144.8 & 94.1 \\
\hline 4.5 & 2115.0 & 1837.0 & 1986.4 & 1836.8 & 128.6 & 0.2 \\
\hline 5.0 & 2312.1 & 1924.6 & 2224.8 & 2057.2 & 87.3 & $(132.6)$ \\
\hline 5.5 & 2477.0 & 1967.4 & - & - & - & - \\
\hline 6.0 & 2602.8 & 1959.4 & - & - & - & - \\
\hline 6.5 & 2682.4 & 1894.7 & - & - & - & - \\
\hline 7.0 & 2708.7 & 1767.3 & - & - & - & - \\
\hline
\end{tabular}

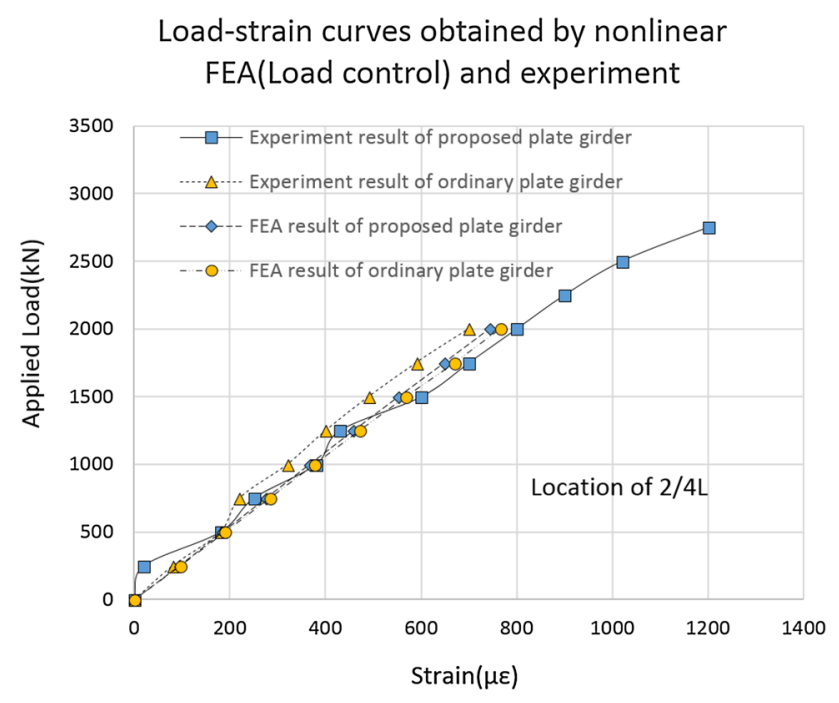

Fig. 8 Comparison of load-strain curves obtained by experiment and nonlinear FEA (load control) at 2/4L

to the material nonlinear finite element analysis of the load control system. Figure 8 is a comparison of the material nonlinear finite element analysis of the load control method and the experimental results for the relation between the load and the maximum strain at the center portion. As shown in
Table 4, the center maximum strain obtained by the finite element analysis of the load control system is similar to the experimental result up to about $2000 \mathrm{kN}$ with a maximum of $80.1 \mu \varepsilon$. In other words, it is confirmed that the shear buckling resistance of the proposed plate girder is improved by the increase in the stiffness and ductility of the girder under the same conditions.

Figure 9 is a comparison of the material nonlinear finite element analysis of the displacement control method and the experimental results for the relation between the load and the maximum deflection at the center. The maximum deflection of the central part obtained by the finite element analysis of the displacement control method was similar to the experimental results up to the maximum force of $1750 \mathrm{kN}$ with a maximum difference of $0.2 \mathrm{~mm}$. In other words, it is confirmed that the proposed girder has higher strength and ductility than general plate girder.

As shown in Table 5 and Fig. 10, the strains at the 1/4L span of ordinary plate girder were significantly different from those of the proposed girder at $750 \mathrm{kN}$. This suggests that horizontal plate buckling of the normal plate girders occurs earlier than the proposed girder, respectively. As shown in Table 6, the deflection profiles for the applied load were similar in comparison of the material nonlinear finite element modeling with the displacement control method. 
Table 4 Load-strain relationship results of experiment at $2 / 4 \mathrm{~L}$

\begin{tabular}{|c|c|c|c|c|c|c|}
\hline \multirow{2}{*}{$\begin{array}{l}\text { Applied } \\
\text { load }(\mathrm{kN})\end{array}$} & \multicolumn{6}{|l|}{$\varepsilon_{\mathrm{m}}(\mu \varepsilon)$} \\
\hline & $\begin{array}{l}\text { Experiment result of } \\
\text { proposed plate girder }\end{array}$ & $\begin{array}{l}\text { Experiment result of } \\
\text { ordinary plate girder }\end{array}$ & $\begin{array}{l}\text { FEA result of pro- } \\
\text { posed plate girder }\end{array}$ & $\begin{array}{l}\text { FEA result of ordi- } \\
\text { nary plate girder }\end{array}$ & $\begin{array}{l}\text { Error of proposed } \\
\text { plate girder }\end{array}$ & $\begin{array}{l}\text { Error of } \\
\text { ordinary plate } \\
\text { girder }\end{array}$ \\
\hline 0 & 0 & 0 & 0 & 0 & 0.0 & 0.0 \\
\hline 250 & 20 & 80 & 94.1293 & 96.415 & (74.1) & (16.4) \\
\hline 500 & 180 & 180 & 184.762 & 189.876 & (4.8) & (9.9) \\
\hline 750 & 250 & 220 & 275.5 & 283.337 & $(25.5)$ & (63.3) \\
\hline 1000 & 380 & 320 & 366.42 & 376.91 & 13.6 & (56.9) \\
\hline 1250 & 430 & 400 & 458.233 & 471.489 & $(28.2)$ & (71.5) \\
\hline 1500 & 600 & 490 & 552.074 & 568.197 & 47.9 & (78.2) \\
\hline 1750 & 700 & 590 & 647.88 & 670.081 & 52.1 & $(80.1)$ \\
\hline 2000 & 800 & 700 & 742.54 & 766.232 & 57.5 & $(66.2)$ \\
\hline 2250 & 900 & - & - & - & - & - \\
\hline 2500 & 1020 & - & - & - & - & - \\
\hline 2750 & 1200 & - & - & - & - & - \\
\hline
\end{tabular}

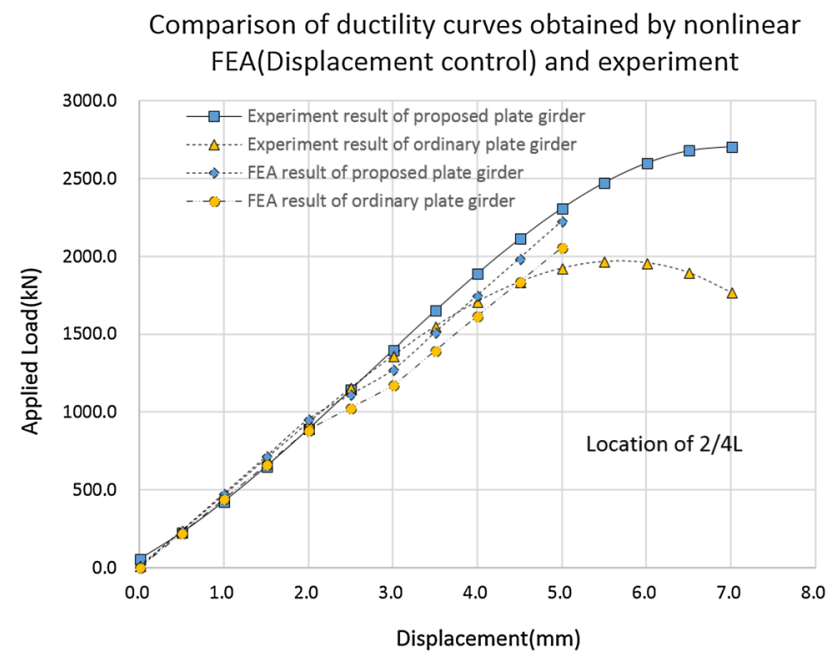

Fig. 9 Comparison of ductility curves obtained by experiment and nonlinear FEA (displacement control) at 2/4L

\section{Conclusions}

In this study, shear buckling test and material nonlinear finite element analysis of the proposed and ordinary plate girder were carried out. The results can be summarized as follows.

1. The proposed CEP-FIP 1990 material nonlinear finite element results are similar to the shear buckling test results when the maximum deflection displacement is $0.2 \mathrm{~mm}$ when the displacement control method is used.

2. Results of shear buckling test and material nonlinear finite element analysis show that the proposed girder has 1.5 times the applied load difference up to maximum
Table 5 Load-strain relationship results of experiment at 1/4L

\begin{tabular}{lll}
\hline Applied load $(\mathrm{kN})$ & \multicolumn{1}{c}{$\varepsilon_{\mathrm{q}}(\mu \varepsilon)$} & \\
\cline { 2 - 3 } & Proposed plate girder & $\begin{array}{l}\text { Ordinary } \\
\text { plate girder }\end{array}$ \\
\hline 0 & 0 & 0 \\
250 & 10 & 30 \\
500 & 80 & 100 \\
750 & 130 & 130 \\
1000 & 185 & 180 \\
1250 & 210 & 190 \\
1500 & 230 & 200 \\
1750 & 280 & 205 \\
2000 & 300 & 185 \\
2250 & 320 & - \\
2500 & 390 & - \\
2750 & 420 & - \\
\hline
\end{tabular}

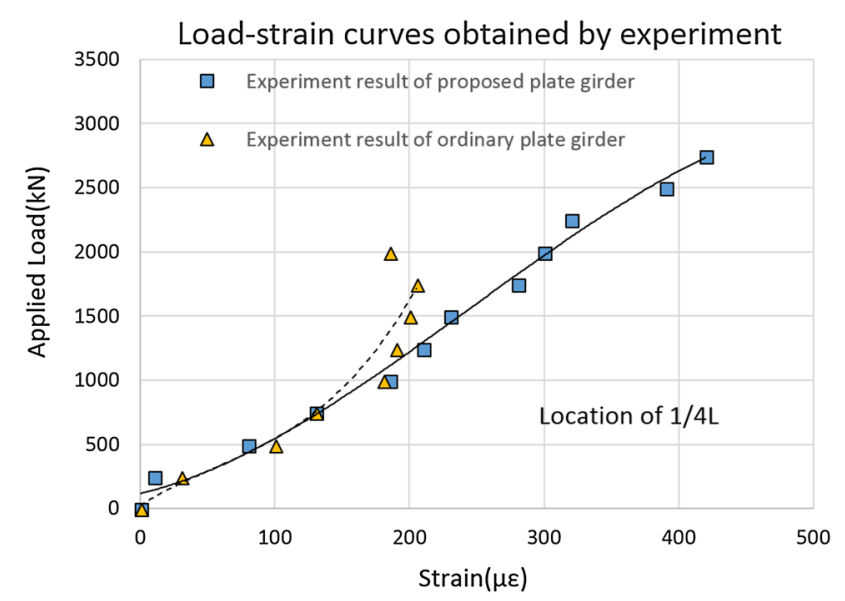

Fig. 10 Results of load-strain curves obtained by experiment at $1 / 4 \mathrm{~L}$ 
Table 6 Deformation results of experiment and FEA

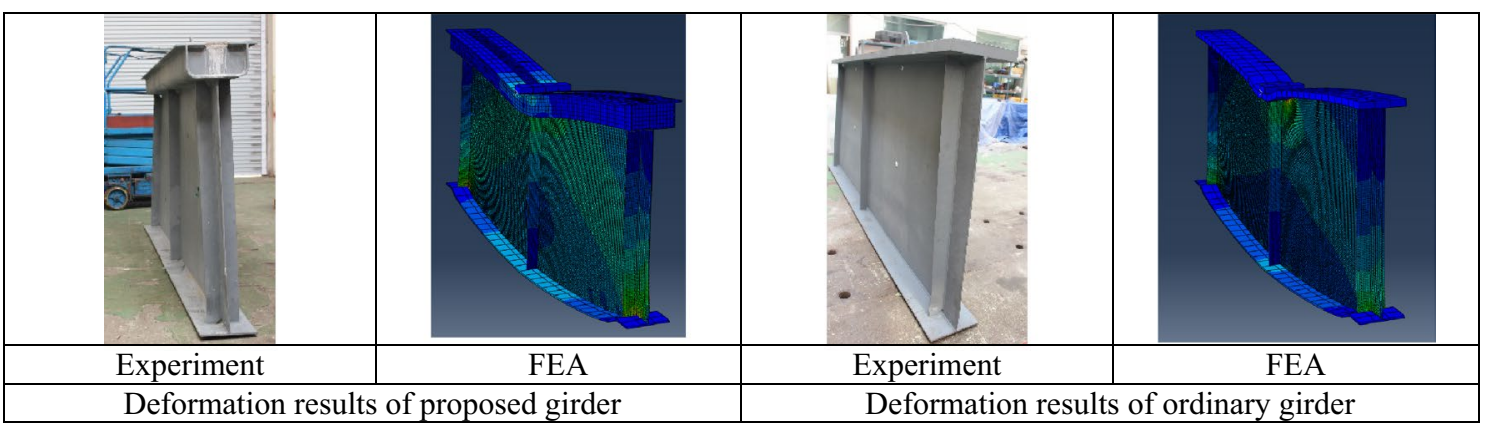

flexural displacement than the ordinary plate girder. In other words, it is confirmed that the proposed girder exhibits confinement effect of the concrete-filled steel tube structure, so that the strength and ductility are increased as compared with the general plate.

3. As a result of shear buckling comparison test, the strain at the $1 / 4 \mathrm{~L}$ span was suddenly generated at the plate girder than the proposed girder at $750 \mathrm{kN}$. That is, through the mock-up experiment, we found that the newly proposed girder improves the shear buckling resistance performance compared to the general plate girder.

Acknowledgements This research was supported by Grants from Korea Bridge Institute Co., Ltd.

Open Access This article is distributed under the terms of the Creative Commons Attribution 4.0 International License (http://creativeco mmons.org/licenses/by/4.0/), which permits unrestricted use, distribution, and reproduction in any medium, provided you give appropriate credit to the original author(s) and the source, provide a link to the Creative Commons license, and indicate if changes were made.

\section{References}

Bambach MR et al (2008) Hollow and concrete filled steel hollow sections under transverse impact loads. Eng Struct 30(10):28592870. https://doi.org/10.1016/j.engstruct.2008.04.003

Baskar K et al (2002) Finite-element analysis of steel-concrete composite plate girder. J Struct Eng 128(9):1158-1168. https://doi. org/10.1061/(ASCE)0733-9445(2002)128:9(1158)

CEB (1993) CEB-FIP model code 1990. Thomas Telford, London

Chen XW et al (2018) Shear buckling behaviour of welded stainless steel plate girders with transverse stiffeners. Thin Walled Struct 122:529-544. https://doi.org/10.1016/j.tws.2017.10.043
Darmawan AR et al (2018) Perilaku plate girder Badan Bergelombang. Rekayasa Sipil 11(2):116-123. https://doi.org/10.21776/ub.rekay asasipil/2017.011.02.5

Höglund T (1997) Shear buckling resistance of steel and aluminium plate girders. Thin Walled Struct 29(1-4):13-30. https://doi. org/10.1016/S0263-8231(97)00012-8

$\mathrm{Hu} \mathrm{HT}$ et al (2003) Nonlinear analysis of axially loaded concrete-filled tube columns with confinement effect. J Struct Eng 129(10):1322-1329. https://doi.org/10.1061/ (ASCE)0733-9445(2003)129:10(1322)

Lee SC, Yoo CH (1998) Strength of plate girder web panels under pure shear. J Struct Eng 124(2):184-194. https://doi.org/10.1061/ (ASCE)0733-9445(1998)124:2(184)

Lee SC et al (1996) Shear buckling coefficients of plate girder web panels. Comput Struct 59(5):789-795. https://doi.org/10.1016/00457949(95)00325-8

Nakamura S et al (2002) New technologies of steel/concrete composite bridges. J Constr Steel Res 58(1):99-130. https://doi.org/10.1016/ S0143-974X(01)00030-X

Okamoto Y et al (2012) Study on steel box girder bridges partly stiffened by CFT arch ribs. J Constr Steel Res 70:28-35. https://doi. org/10.1016/j.jcsr.2011.08.012

Sim JG (2017) Evaluation of static structural performance of a plate composite girder using CFT structures. KSCE J Civ Eng 21(4):1424-1433

Specifications (2012) AASHTO specifications. American Association of State Highway and Transportation Officials, Washington, DC

Wu Q, Yoshimura M, Takahashi K, Nakamura S, Nakamura T (2006) Nonlinear seismic properties of the second Saikai bridge: a concrete filled tubular (CFT) arch bridge. Eng Struct 28(2):163-182. https://doi.org/10.1016/j.engstruct.2005.05.003

Publisher's Note Springer Nature remains neutral with regard to jurisdictional claims in published maps and institutional affiliations. 